\title{
Penurunan Kadar Tanin Silase Kulit Pisang dengan Menggunakan Berbagai Aditif
}

\section{Decreasing of Tannins from Banana Peel Silage with Different Additives}

\author{
T. N. I. Koni ${ }^{1}$ dan T. A. Y. Foenay ${ }^{2}$ \\ ${ }^{1}$ Program Studi Teknologi Pakan Ternak, Jurusan Peternakan, Politeknik Pertanian Negeri Kupang, \\ ${ }^{2}$ Program Studi Produksi Ternak, Jurusan Peternakan, Politeknik Pertanian Negeri Kupang \\ Jl. Prof. Dr. Herman Yohanis, Lasiana, Kupang 85011, NTT, Indonesia \\ Corresponding email: Indahkoni@gmail.com
}

\begin{abstract}
This study was aimed to evaluate the effect of soluble carbohydrates as an additive on tannins, dry matter, crude protein and crude fat content of banana peel silage. This study used an experimental method with a completely randomized design with three treatments and five replications. The three treatments were (P0) silage of banana peels without additives: (P1) silage of banana peels with the addition of 5\% rice bran; $(\mathrm{P} 2)$ silage of banana peels with the addition of 5\% tapioca. The parameters measured were tannin, dry matter, and crude protein content. Data were analyzed by analysis of variance and if it had a significant effect it was followed by Duncan's multiple range test. The results showed that the use of 5\% rice bran and 5\% tapioca decreased tannins as much as $41 \%$ and $43 \%$, respectively. Tannins when compared to silage without additives, and increased protein content of $19.7 \%$ and $46.4 \%$, and increased crude fat of $6.95 \%$ and $33.30 \%$, respectively, compared to silage without additives.
\end{abstract}

Key words: silage, banana peel, tannin, crude protein, crude fat

\begin{abstract}
ABSTRAK
Penelitian ini bertujuan untuk mengevaluasi pengaruh penggunaan karbohidrat mudah larut sebagai aditif terhadap kandungan tanin, bahan kering protein kasar dan lemak kasar silase kulit pisang. Metode eksperimen digunakan dalam penelitian ini dengan rancangan acak lengkap dengan tiga perlakuan dan lima ulangan. Tiga perlakuan adalah (P0) silase kulit pisang tanpa aditif; (P1) silase kulit pisang dengan penambahan bekatul 5\%; (P2) silase kulit pisang dengan penambahan tapioka 5\%. Parameter yang diukur adalah tanin, bahan kering, dan kadar protein kasar. Data dianalisis menggunakan analisis ragam dan jika berpengaruh nyata maka dilanjutkan dengan uji jarak berganda Duncan. Hasil penelitian menunjukkan bahwa penggunaan dedak padi 5\% dan tapioka 5\% menurunkan tanin masing-masing 41\% dan $43 \%$ tanin bila dibandingkan dengan silase tanpa aditif, peningkatan kandungan protein sebesar $19,7 \%$ dan $46,4 \%$ dan peningkatan kadar lemak kasar sebesar $6,95 \%$ dan $33,3 \%$ bila dibandingkan dengan silase tanpa aditif.
\end{abstract}

Kata kunci: silase, kulit pisang, tanin, protein kasar, lemak kasar

\section{PENDAHULUAN}

Pisang kepok (Musa paradisiaca) adalah jenis pisang yang digunakan untuk memproduksi berbagai olahan seperti kripik, pisang goreng. Berat kulit pisang kepok sekitar 25 - 40\% dari berat buah pisang (Koni et al., 2013; Wadhwa and Bakshi, 2013). Produksi pisang di Nusa Tenggara Timur (NTT) pada tahun 2017 mencapai 92.988,40 ton (Badan Pusat Statistik, 2018) hal ini berarti produksi kulit pisang sekitar 23.247,1 ton.

Kulit pisang merupakan salah satu limbah pertanian yang dapat dijadikan sebagai pakan ternak, kandungan protein kasar mencapai 8\%, lemak kasar 6,2\% (Wadhwa and Bakshi, 2013), lemak kasar 2,52\%, serat kasar 18,71\%
(Koni, 2013); Ca 0,27 dan pospor 0,26\% (Fitroh et al., 2018). Selain kandungan nutrien kulit pisang juga mengandung tanin sebesar 4,97\% (Hudiansyah et al., 2015). Adanya senyawa tanin akan menurunkan konsumsi, pertumbuhan dan konversi pakan pada ternak ayam broiler (Dei et al., 2008).

Pengolahan pakan dengan cara fermentasi merupakan metode yang dapat menurunkan kadar tanin (Dei et al., 2008) dan pembuatan silase merupakan cara terbaik untuk menurunkan kadar tanin total pada Chorolena odorata (Ridla et al., 2016). Salah satu cara perbaikan kualitas silase dengan penambahan sumber karbohidrat yang mudah dicerna seperti dedak halus, dan tapioka. Penambahan aditif pada silase menyediakan tambahan karbohidrat 
mudah larut untuk dimanfaatkan oleh mikroorganisme sebagai sumber energi (Anas dan Syahrir, 2017; Handayani et al., 2018), selain itu penambahan aditif dapat mempercepat penurunan $\mathrm{pH}$ sehingga membatasi pemecahan protein dan menghambat pertumbuhan mikroorganisme aerobik merugikan (Nurmi et al., 2018).

Penambahan berbagai sumber karbohidrat pada pembuatan silase kulit pisang dapat mencukupi kebutuhan karbohidrat mudah larut bagi mikroorganisme sehingga mempercepat proses ensilase. Kajian penggunaan berbagai macam aditif pada pembuatan silase kulit pisang belum dilakukan sehingga penelitian ini bertujuan untuk mengkaji pengaruh penggunaan berbagai jenis aditif terhadap kandungan tanin, bahan kering dan protein kasar silase kulit pisang.

\section{MATERI DAN METODE}

Bahan yang digunakan dalam penelitian ini adalah kulit pisang kepok yang diperoleh dari tempat pengolahan pisang, dedak padi, dan tepung tapioka. Alat yang digunakan meliputi silo dari stoples plastik kapasitas $1 \mathrm{~kg}$ serta alat lainnya untuk analisis kandungan total tanin dan kandungan bahan kering, protein kasar silase kulit pisang. Penelitian ini terdiri dari dua tahap yaitu tahap pembuatan silase dan tahap analisis laboratorium.

\section{Pembuatan Silase}

Proses pembuatan silase kulit pisang berdasarkan petujuk Larangahen et al. (2017) yaitu: kulit pisang yang dipilih diambil dari tempat pengolahan pisang. Kulit pisang dicuci dengan menggunakan air bersih, kemudian ditiriskan, dilanjutkan dengan pemotongan, kulit pisang dipotong $\pm 3 \mathrm{~cm}$, dan dibiarkan layu hingga 4 jam. Penambahan dengan aditif sesuai dengan perlakuan, kemudian kulit pisang dimasukan dalam silo dan dipadatkan, silo ditutup hingga rapat dan diinkubasi pada suhu ruang selama 21 hari. Setelah 21 hari dilakukan pemanenan silase, kemudian dikeringkan dalam oven $60^{\circ} \mathrm{C}$ kemudian dinalisis kandungan tanin, bahan kering dan protein kasar.

Penelitian pembuatan silase kulit pisang ini menggunakan 3 perlakuan penambahan aditif, yaitu $\mathrm{P0}=$ silase kulit pisang tanpa aditif, $\mathrm{P} 1=$ kulit pisang $+5 \%$ dedak padi, $\mathrm{P} 2=$ kulit pisang $+5 \%$ tapioka. Setiap perlakuan diulang 5 kali.

\section{Analisis Laboratorium}

Analisis sampel meliputi analisis total tanin, bahan kering dan kandungan protein silase kulit pisang. Analisis total tanin menggunakan metode Burns (1971), kandungan bahan kering dan protein kasar (PK) menggunakan metode AOAC (2005).

\section{Analisis Data}

Data dianalisis menggunakan ANOVA (Analysis of Variance) untuk mengetahui pengaruh perlakuan terhadap parameter yang diamati, bila terdapat pengaruh maka dilanjutkan dengan uji lanjut Duncan $(\mathrm{P}<0,05)$.

\section{HASIL DAN PEMBAHASAN}

\section{Produksi Pisang di NTT}

Pisang merupakan salah satu pangan pokok yang dikonsumsi oleh masyarakat di NTT (Arifin, 2010). Produksi pisang setiap kabupaten di NTT ditampilkan pada Tabel 1. Dari Tabel 1 terlihat bahwa pada tahun 2017 terjadi penurunan sekitar 33,97\% produksi pisang di NTT dibandingkan dengan tahun 2016. Hal ini kemungkinan karena adanya pergeseran penggunaan lahan pertanian. Kulit pisang mempunyai berat $25-40 \%$ dari berat buah pisang tergantung pada tingkat kematangannya, semakin matang maka berat kulit pisang semakin berkurang (Koni 2013). Berdasarkan data pada Tabel 1 maka berat kulit buah pisang yang dihasilkan di NTT pada tahun 2017 berkisar 23.247,1 - 37.195,36 ton.

\section{Kandungan Tanin Silase Kulit Pisang}

Pengaruh penggunaan karbohidrat mudah larut sebagai aditif pada pembuatan silase terhadap kadar tanin ditampilkan pada Gambar 1.

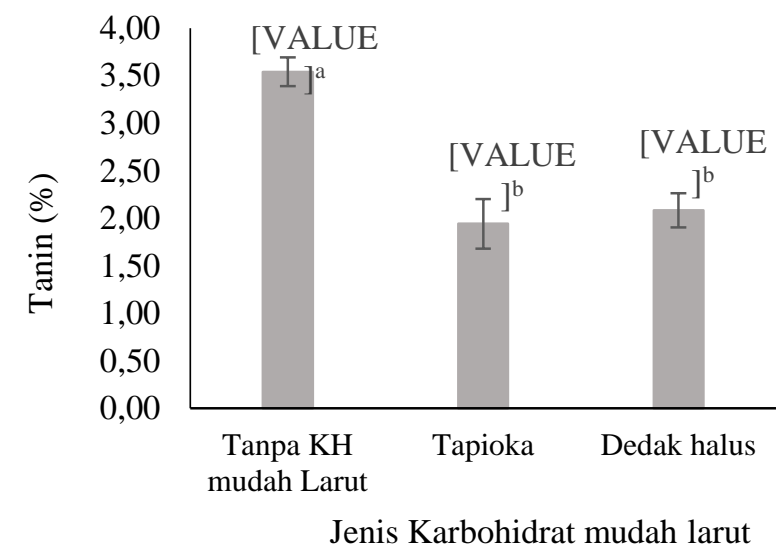

Gambar 1. Pengaruh penggunaan karbohidrat mudah larut terhadap kadar tanin silase kulit pisang Error bar menunjukkan standar deviasi 
Tabel 1. Produksi pisang setiap kabupaten di NTT

\begin{tabular}{lrrrr}
\hline Kabupaten & \multicolumn{4}{c}{ Produksi Pisang (ton) } \\
\cline { 2 - 5 } & 2014 & 2015 & 2016 & 2017 \\
\hline Sumba Barat & 1464,90 & 4483,6 & 1522,2 & 9326,4 \\
Sumba Timur & 2072,90 & 14432,8 & 679.60 & 1052,30 \\
Kupang & 20869,60 & $18,321,5$ & 13555,4 & 4567,8 \\
Timor Tengah Selatan & 13420,2 & 12285,7 & 4985,7 & 8608,2 \\
Timor Tengah Utara & 11853,3 & 4193,6 & 3160,7 & 1632,5 \\
Belu & 1444,5 & 2727,5 & 3318,2 & 1394,2 \\
Alor & 5596,7 & 4294,2 & 4231,1 & 5555,1 \\
Lembata & 2611,1 & 2573,8 & 4727 & 4222,2 \\
Flores Timur & 3912,2 & 4622 & 6222,9 & 427.4 \\
Sikka & 5738 & 928,9 & 8235,8 & 22489,5 \\
Ende & 2106,4 & 1790,7 & 1140,7 & 229,9 \\
Ngada & 7307,6 & 5507,3 & 1841,2 & 7 \\
Manggarai & 3497,90 & 1551,3 & 1019,3 & 690,5 \\
Rote Ndao & 746,8 & 755,20 & 378,6 & 485,6 \\
Manggarai Barat & 3523 & 9429,4 & 29343,3 & 18089 \\
Sumba Tengah & 1202,9 & 1471,6 & 200,8 & 189,4 \\
Sumba Barat Daya & 12447,9 & 2136,3 & 1287,7 & 720,4 \\
Nagekeo & 5682 & 7747,9 & 4151 & 4357,9 \\
Manggarai Timur & 24031 & 8511 & 34541,1 & 8751,3 \\
Sabu Raijua & 140,6 & 130 & 100,1 & 36,9 \\
Malaka & & & 15851,6 & 12,9 \\
Kota Kupang & 203,7 & 313,5 & 321 & 142 \\
NTT & $\mathbf{1 2 9 8 7 8 , 2}$ & $\mathbf{1 0 8 2 9 7 , 8}$ & $\mathbf{1 4 0 8 3 3}$ & $\mathbf{9 2 9 8 8 , 4}$ \\
\hline
\end{tabular}

Sumber: Badan Pusat Statistik (2018)

Analisis varians menunjukkan bahwa penggunaan aditif berpengaruh nyata $(\mathrm{P}<0,05)$ terhadap penurunan kandungan tanin silase kulit pisang. Penurunan kadar tanin pada silase tanpa penambahan aditif lebih rendah daripada yang menggunakan aditif. Penurunan tertinggi pada perlakuan yang menggunakan aditif dedak padi 5\%. Penambahan aditif mendukung perkembangan bakteri asam laktat sehingga proses ensilase berjalan dengan baik. Pertumbuhan mikroorganisme yang baik menyebabkan enzim yang dihasilkan pun semakin banyak termasuk enzim pendegradasi tanin. Jadi penggunaan karbohidrat mudah larut tidak berkontribusi langsung menurunkan tanin pada kulit pisang tetapi mempercepat proses ensilase sehingga mikroorganisme penghasil asam laktat lebih cepat berkembang. Pada pembuatan silase adanya aktivitas bakteri asam laktat (Unaya et al., 2015). Shang et al. (2019) menyatakan bahwa bakteri asam laktat dapat mendegradasi tanin hingga $78 \%$ tanin pada Xuan mияиа.

Kulit pisang memiliki kandungan anti nutrisi berupa tanin yaitu 4,97 \% (Hudiansyah et al., 2015) maka proses ensilase kulit pisang dapat menurunkan kadar tanin 28,77 hingga 59,96\%. Mullik et al. (2016) melaporkan bahwa penurunan total tanin $62 \%$ pada silase Chromolena odorata tanpa aditif. Murwan dan Ali (2011) menyatakan bahwa penurunan tanin pada sorgum yang difermentasi karena adanya aktifitas mikroorganisme selama proses fermentasi.

\section{Kandungan Bahan Kering Silase Kulit Pisang}

Pengaruh penggunaan karbohidrat mudah larut sebagai aditif terhadap kadar bahan kering, protein kasar, lemak kasar silase kulit pisang disajikan pada Tabel 2.

Hasil analisis varians menunjukkan bahwa perbedaan jenis karbohidrat mudah larut tidak berpengaruh nyata terhadap kadar bahan kering silase kulit pisang. Hal ini berarti bahwa penambahan silase aditif sebanyak $5 \%$ tidak mempengaruhi perubahan bahan kering silase kulit pisang yang dihasilkan. Henderson (1993) menyatakan bahwa penambahan sumber karbohidrat dalam pembuatan silase akan menyebabkan peningkatan kadar bahan kering substrat karena karbohidrat sebagai aditif silase memacu aktifitas fermentasi. 
Tabel 2. Pengaruh penambahan berbagai karbohidrat mudah larut terhadap bahan kering, protein kasar, lemak kasar silase kulit pisang

\begin{tabular}{llll}
\hline Komponen & \multicolumn{3}{c}{ Perlakuan } \\
\cline { 2 - 4 } & $\mathrm{P}_{0}$ & $\mathrm{P}_{1}$ & $\mathrm{P}_{2}$ \\
\hline Bahan kering (\%) & $94,762 \pm 0,54$ & $94,948 \pm 0,64$ & $95,252 \pm 0,41$ \\
Protein kasar (\%) & $6,608 \pm 0,29$ & $7,952 \pm 1,17^{\mathrm{b}}$ & $9,660 \pm 0,72^{\mathrm{a}}$ \\
Lemak kasar (\%) & $11,076 \pm 0,10^{\mathrm{c}}$ & $11,836 \pm 0,39^{\mathrm{b}}$ & $14,768 \pm 0,54^{\mathrm{a}}$ \\
\hline a,b,c Superskrip yang berbeda pada baris yang sama menunjukkan perbedaan nyata $(\mathrm{P}<0,05),\left(\mathrm{P}_{0}\right)=$ Kulit pisang \\
tanpa penambahan karbohidrat mudah larut, $\left(\mathrm{P}_{1}\right)=$ kulit pisang dengan penambahan tapioka 5\%, $\left(\mathrm{P}_{2}\right)=$ kulit \\
pisang dengan penambahan dedak 5\%
\end{tabular}

Bila dibandingkan dengan bahan kering kulit pisang tanpa fermentasi dengan kadar bahan kering 95,76\% (Koni, 2013), maka proses fermentasi (silase) menurunkan kadar bahan kering kulit pisang, baik pada kulit pisang tanpa penggunaan karbohidrat mudah larut maupun yang menggunakan dedak dan tapioka. Hal ini karena dalam proses fermentasi mikroorganisme menggunakan nutrien dalam substrat untuk pertumbuhannya. Penurunan kadar bahan kering pada bahan yang difermentasi disebabkan oleh aktivitas metabolisme mikroorganisme selama proses fermentasi (Adegbehingbe et al., 2014; Oluwamiyi and Bazambo, 2016). Penurunan bahan kering ini disebabkan karena aktivitas metabolisme mikroorganisme menghasilkan $\mathrm{H}_{2} \mathrm{O}$ (air), sehingga kandungan air dalam substrat pun bertambah dan kadar bahan kering menurun (Olagunju and Ifesan, 2013).

\section{Kandungan Protein Kasar Silase Kulit Pisang}

Perbedaan silase aditif yang digunakan berpengaruh nyata $(\mathrm{P}<0,05)$ terhadap kadar protein kasar silase kulit pisang. Peningkatan protein kasar pada silase kulit pisang yang menggunakan aditif. Hal ini disebabkan penggunaan silase aditif mendukung pertumbuhan mikroorganisme sehingga semakin tinggi protein kasar yang ada pada substrat yang difermentasi. Kadar protein kasar tertinggi pada silase kulit pisang yang menggunakan dedak padi sebagai silase aditif. Hal ini disebabkan karena kandungan protein kasar dedak padi yaitu sekitar $13 \%$ paling tinggi daripada aditif lainnya. Kadar protein kasar dedak padi 13\% (Wahju 2015) dan kandungan protein kasar tepung tapioka 2,4\% (Parakkasi 1983). Ohmomo et al. (2002) menyatakan bahwa kualitas dan kandungan protein bahan baku akan mempengaruhi kandungan protein bahan yang difermentasi.

Proses fermentasi seperti pembuatan silase meningkatkan kadar protein kasar bahan yang difermentasi. Kulit pisang tanpa fermentasi mempunyai kandungan protein kasar 3,63\% (Koni, 2013). Mendoza et al. (1994) menyatakan bahwa pada proses ensilase kadar protein akan meningkatkan karena terbentuknya protein sel tunggal. Pada penelitian (Salombre et al., 2018) terjadi peningkatan kadar protein kasar dari $6,61 \%$ sebelum dibuat silase menjadi $10,6 \%$ pada silase kulit pisang.

\section{Kandungan Lemak Kasar Silase Kulit Pisang} Perbedaan jenis silase aditif yang digunakan berpengaruh nyata $(\mathrm{P}<0,05)$ terhadap kandungan lemak kasar silase kulit pisang. Penggunaan silase aditif meningkatkan kadar lemak kasar silase kulit pisang. Hal ini karena penggunaan aditif memberi sumbangan penambahan lemak kasar.

Kandungan lemak kasar tertinggi ada pada silase dengan bahan aditif dedak padi hal ini disebabkan oleh kandungan lemak yang tinggi pada dedak padi. Kandungan lemak pada dedak padi sebesar 13\% (Wahju 2015). Bakrie et al. (2017) menyatakan bahwa dedak padi merupakan aditif yang mengandung protein, karbohidrat mudah larut dan minyak yang tinggi. Penambahan aditif 5\% dedak padi menghasilkan kadar lemak kasar tertinggi pada silase rumput mulato (Anas dan Syahrir, 2017).

Kadar lemak kasar pada penelitian ini berkisar 11,08-14,77\%. Kadar lemak kasar pada penelitian ini lebih tinggi daripada silase kulit pisang kepok hasil penelitian Salombre et al., (2018) yang melaporkan bahwa kadar lemak silase kulit pisang sebesar $7,7 \%$. Perbedaan kandungan lemak kasar ini kemungkinan disebabkan karena adanya perbedaan kadar lemak kasar kulit pisang yang digunakan dan perlakuan pembuatan silase. Ojokoh et al. (2013) menyatakan bahwa terjadi peningkatan kandungan nutrien Treculia africana dan Vigna unguiculata yang difermentasi secara natural selama 72 jam yaitu peningkatan protein kasar 
8,91 menjadi $10,27 \%$, lemak kasar 2,82 menjadi $3,28 \%$ dan penurunan serat kasar yaitu 2,60 menjadi $2,46 \%$ serta penurunan oksalat dari 2,38 menjadi $0,83 \mathrm{mg} / 100 \mathrm{~g}$.

\section{KESIMPULAN}

Penggunaan aditif tapioka 5\% menurunkan kadar tanin tertinggi pada silase kulit pisang. Penggunaan aditif tidak beroengaruh terhadap kadar bahan kering silase kulit pisang, namun penggunaan dedak padi 5\% sebagai silase aditif mampu menghasilkan protein kasar dan lemak kasar tertinggi pada silase kulit pisang. Sebelum digunakan sebagai pakan maka kulit pisang diolah dengan cara pembuatan silase dan menggunakan aditif seperti tapioka atau dedak padi.

\section{UCAPAN TERIMA KASIH}

Penulis mengucapkan terima kasih kepada Politeknik Pertanian Negeri Kupang, yang telah membiayai kegiatan ini melalui Penelitian Dasar Terapan PNBP Tahun Anggaran 2019.

\section{DAFTAR PUSTAKA}

Adegbehingbe, K. T., F. C. Adetuyi, and F.A. Akinyosoye. 2014. Effect of fermentation on nutrient and anti- nutrient contents of ground-cooked lima bean (Phaseolus lunatus) seeds using Bacillus subtilis and Bacillus pumilus. British Microbiology Research Journal 4 (11): 1285-98.

Anas, M.A. and Syahrir. 2017. Pengaruh penggunaan jenis aditif sebagai sumber karbohidrat terhadap komposisi kimia silase rumput mulato. Jurnal Agrisains 18 (1): 13-22.

AOAC. 2005. Official Methods of Analysis of the Association of Official Analytical Chemists. 18th ed. Washington, DC.: Association of Official Analytical Chemist.

Arifin, Z. 2010. Penataan lahan mamar pisang berbasis pertanian terpadu. Partner 17 (2): 188-95.

Badan Pusat Statistik. 2018. Statistik Pertanian NTT.
Bakrie, B., Y. Sastro, and N. R. Sudolar. 2017. Effect of different accellerators and inoculums used in fermentation on quality of dead chicken silage flour as feed ingredient for catfish. Journal of the Indonesian Tropical Animal Agriculture 42 (2): 99-108.

Burns, R.E. 1971. Method for estimation of tannin in grain sorghum. Agronomy Journal 63: 511-12.

Dei, H. K., S. P. Rose, and A. M. Mackenzie. 2008. Effects of Fungal (Aspergillus niger or Ceriporiopsis subvermispora) fermentation on the nutritive value of shea nut ( Vitellaria paradoxa) meal for broiler chicks. British Poultry Science 49: 360-67.

Fitroh, B. A., Wihandoyo, and Supadmo. 2018. The use 3 of banana peel meal (Musa paradisiaca) as substitution of corn in the diets on performance and carcass production of hybrid ducks. Buletin Peternakan 42 (3): 222-31.

Handayani, S., A. E. Harahap, and E. Saleh. 2018. Kandungan fraksi serat silase kulit pisang kepok (Musa paradisiaca) dengan penambahan level dedak dan lama pemeraman yang berbeda. Jurnal Peternakan 15 (1): 1-8.

Henderson, N. 1993. Silage additives. Animal Feed Science and Technolgy 45: 35-56.

Hudiansyah, P., D. Sunarti, and B. Sukamto. 2015. Pengaruh penggunaan kulit pisang terfermentasi dalam ransum terhadap ketersediaan energi ayam broiler. Agromedia 33 (2): 1-9.

Koni, T. N.I. 2013. Effect of fermented banana peel on broiler carcass. Jurnal Ilmu Ternak dan Veteriner 18 (2): 153-57.

Koni, T. N. I., J. Bale-Therik, and P. R. Kale. 2013. Utilizing of fermented banana peels by Rhyzopus oligosporus in ration on growth of broiler. Jurnal Veteriner 14 (3): $365-70$.

Larangahen, A., B Bagau, M. R. Imbar, and H. Liwe. 2017. Pengaruh penambahan 
molases terhadap kualitas fisik dan kimia silase kulit pisang sepatu (Mussa paradisiaca formatypica). Jurnal Zootek 37 (1): 156-66.

Mendoza, N. S., M. Arai, T. Kawaguchi, F. S. Cubol, E. G. Panerio, T. Yoshida, and L. M. Johson. 1994. Isolation of mannan utilizing bacteria and the culture condition for mannanase production. World Journal of Microbiology and Biotechnologi 10 (1): 51-54.

Mullik, Y.M, M. Ridla, I Prihantoro, and M. L. Mullik. 2016. Anaerobic fermentation effectively reduces concentration of total tannins in Chromolaena odorata. JITV. 21 (1): 19-25.

Murwan, K. S. E., and A. A. Ali. 2011. Effect of fermentation period on the chemical composition, in-vitro protein digestibility and tannin content in two sorghum cultivars (Dabar and Tabat) in Sudan. Journal of Applied Biosciences 39: 2602-6.

Nurmi, A., M. A. Santi, N. Harahap, and M. F., Harahap. 2018. Percentage of carcass and mortality of broiler and native chicken fed with unfermented and fermented arenga waste. Jurnal Ilmiah Peternakan Terpadu 6 (3): 134-39.

Ohmomo, S., O. Tanaka, H. K., Kitamoto, and Y. Cai. 2002. Silage and microbial performance, old story but new problems. JARQ 36 (2): 59-71.

Ojokoh, A. O., M. K. Daramola, and O. J. Oluoti. 2013. Effect of fermentation on nutrient and anti-nutrient composition of breadfruit (Treculia africana) and cowpea (Vigna unguiculata) blend flours. African Journal of Agricultural Research 8 (27): 3566-3570.

Olagunju, A. I, and B.O.T. Ifesan. 2013. Changes in nutrient and antinutritional contents of sesame seeds during fermentation.
Journal of Microbiology, Biotechnology and Food Sciences 2 (6): 2407-10.

Oluwamiyi, O. and I.O. Bazambo. 2016. Nutritional and amino acid analysis of raw, partially fermented and completely fermented locust bean (Parkia biglobosa) seeds. African Journal of Food, Agriculture, Nutrition and Development 16 (2): 10866-83.

Parakkasi, A. 1983. Ilmu Gizi Dan Makanan Ternak Monogastrik. Angkasa. Bandung.

Ridla, M., Y. M. Mullik, I. Prihantoro, and M. L. Mullik. 2016. Penurunan total tanin silase semak bunga putih (Chromolaena odorata) dengan aditif tepung putak (Coryphaelata robx) dan isi rumen sapi. Buletin Peternakan 40 (3): 165-69.

Salombre, V.J., M. Najoan, F.N. Sompie, and M.R. Imbar. 2018. Pengaruh penggunaan silase kulit pisang kepok (Musa paradisiaca formatypica) sebagai pengganti sebagian jagung terhadap karkas dan viscera broiler. Jurnal Zootek 38 (1): 27-36.

Shang, Y., H. Cao, Y. Ma, C. Zhang, F. Ma, and C. Wang. 2019. Effect of lactic acid bacteria fermentation on tannins removal in xuan mugua fruits. Food Chemistry 274: 118-22.

Unaya, S., S. Tantolo, and Liman. 2015. Efek suplementasi berbagai akselerator terhadap kualitas nutrisi silase limbah tanaman singkong. Jurnal Ilmu Peternakan Terpadu 3 (2): 1-5.

Wadhwa and P. S. Bakshi. 2013. Utilization of fruit and vegetable wastes as livestock feed and as substrates for generation of other value added products. Journal of Neurochemistry 105 (2) : 369-379.

Wahju, J. 2015. Ilmu Nutrisi Unggas. 6th ed. Gadjah Mada University Press. Yogyakarta. 